\title{
Bone Marrow-Derived Cells that Populate the Adult Mouse Brain Preserve Their Hematopoietic Identity
}

\author{
Luc Vallières ${ }^{1}$ and Paul E. Sawchenko ${ }^{2}$ \\ ${ }^{1}$ Laboratoire d'Endocrinologie Moléculaire, Centre de Recherche du Centre Hospitalier de l'Université Laval, Université Laval, Québec, Québec, G1V 4G2, \\ Canada, and 2Laboratory of Neuronal Structure and Function, The Salk Institute for Biological Studies, La Jolla, California 92037
}

\begin{abstract}
Cytogenesis in the adult brain can result from the recruitment of circulating precursors, but the proposal that some such cells transdifferentiate into neural elements is controversial. We have reinvestigated this issue by following the phenotypic fate of bone marrow cells expressing the green fluorescent protein transplanted into the systemic circulation of irradiated mice. Thousands of donor-derived cells were detected throughout brains of recipients killed 1-12 months after transplantation, but none displayed neuronal, macroglial, or endothelial characteristics, even after injury. Among those that crossed the endothelium of the cerebral cortex, $>99.7 \%$ were identified as perivascular macrophages. Newly formed parenchymal microglia were found in significant numbers only in the cerebellum and at injury sites. Therefore, bone marrow does supply the mature brain with new specialized cells; however, mesenchymal precursors neither adopt neural phenotypes nor contribute to cerebral vascular remodeling. This continuous traffic of macrophages across the blood-brain barrier provides a vehicle to introduce therapeutic genes into the nervous system.
\end{abstract}

Key words: postnatal neurogenesis; gliogenesis; vasculogenesis; bone marrow stem cells; lineage restriction; transdifferentiation; GFP mice

\section{Introduction}

At maturity, many organs house primordial cells capable of selfrenewal and multilineage differentiation known as adult stem cells. These precursors serve the essential function of generating cell types that populate a given tissue, thereby ensuring its growth and repair (Fuchs and Segre, 2000; Weissman, 2000). Neural stem cells are found in several regions of the mature brain and spinal cord, in which they give rise to astrocytes and oligodendrocytes (Gage, 2000). Influenced by site-specific molecular cues, stem cells confined to the subventricular and hippocampal subgranular zones can also produce new neurons for the olfactory bulb and dentate gyrus, respectively. Current evidence suggests that neural stem cells do not manifest the ability to generate microglia or endothelia. The latter are replenished in adulthood through either the proliferation of preexisting cells or the recruitment of circulating precursors that derive from bone marrow (Lawson et al., 1992; Asahara and Isner, 2002).

A fundamental question in contemporary cell biology is whether stem cells of different tissue origins may be interchangeable when removed from their usual niche and introduced to a new environment that might contain appropriate instructive signals (Anderson et al., 2001; Bjorklund and Svendsen, 2001; Blau et al., 2001; Wells, 2002). Several independent groups have pro-

Received Jan. 13, 2003; revised April 7, 2003; accepted April 14, 2003

This work was supported by startup funds from the Centre de Hospitalier de l'Université Laval (CHUL) Research Center and National Institutes of Health Grant NS-21182. L.V. was supported by postdoctoral fellowships from the Fonds de la Recherche en Santé du Québec (FRSQ) and Canadian Institutes of Health Research in partnership with the Canadian Neurotrauma Research Program and Novartis. L.V. is currently a Chercheur-Bousier of the FRSQ.P.E.S. is a Foundation for Medical Research Investigator. We thank Mr. Carlos Arias, Steve Lacroix, and Nicolas Vallières for technical assistance.

Correspondence should be addressed to Luc Vallières, Laboratoire d'Endocrinologie Moléculaire, Centre de Recherche du CHUL, Université Laval, 2705 boulevard Laurier, Québec, G1V 4G2, Canada. E-mail: Luc.Vallieres@crchul.ulaval.ca.

Copyright $\odot 2003$ Society for Neuroscience $\quad$ 0270-6474/03/235197-11 $\$ 15.00 / 0$ vided evidence that bone marrow cells can be converted into neurons and macroglia in vivo (Eglitis and Mezey, 1997; Kopen et al., 1999; Brazelton et al., 2000; Mezey et al., 2000, 2003; Li et al., 2001; Lu et al., 2001; Nakano et al., 2001; Priller et al., 2001a; Akiyama et al., 2002; Bonilla et al., 2002; Corti et al., 2002; Zhao et al., 2002; Weimann et al., 2003) and in vitro (Ling et al., 1998; Sanchez-Ramos et al., 2000; Woodbury et al., 2000; Kohyama et al., 2001). One of the strategies employed was to introduce labeled bone marrow cells into the systemic circulation of mice with impaired hematopoiesis as a consequence of either lethal irradiation or a mutation of a gene involved in hematopoietic cell development (Eglitis and Mezey, 1997; Brazelton et al., 2000; Mezey et al., 2000; Corti et al., 2002). Donor-derived cells were later detected throughout most brain regions, with significant numbers exhibiting neural characteristics. Depending on the model and survival time, it was estimated that $0.2-2.3 \%$ of the total number of neurons were issued from transplanted cells (Brazelton et al., 2000; Mezey et al., 2000). These findings challenge the prevailing dogmas that stem cells do not cross lineage barriers, and only restricted regions of the mature brain are capable of supporting neurogenesis. If correct, bone marrow would constitute an ideal alternative to embryonic stem cells as a safe, readily available and ethically acceptable source of neural elements for cell and gene therapy.

The transdifferentiation concept raises questions as to whether bone marrow-derived stem cells in the peripheral circulation (Wright et al., 2001) can replenish the pool of neural progenitors after irradiation, whether any cells that take up residence in the nervous tissue retain their potential to proliferate, and whether the phenomenon exhibits any regional specificity in the brain. To address these issues, we used a paradigm described by Brazelton et al., in which bone marrow cells genetically engineered to express the green fluorescent protein (GFP) were trans- 
planted into adult mice exposed to lethal radiation (Brazelton et al., 2000). In characterizing the distribution and phenotype of donor-derived cells newly recruited into normal and injured brains, we failed to find support for the conversion of these cells into neural or endothelial elements.

\section{Materials and Methods}

Animals. Adult male C57BL/6J mice purchased from Jackson Laboratory (Bar Harbor, ME) were adapted to standard laboratory conditions for 1 week and subjected to bone marrow transplantation at 8 weeks of age. Hemizygous transgenic mice expressing GFP under control of the chicken $\beta$-actin promoter and cytomegalovirus enhancer were initially obtained from the same vendor. A colony was then established and maintained in a C57BL/6 J background. GFP mice were used as cell donors at 3-5 months of age. All procedures were approved by the Animal Welfare Committees at the Salk Institute and Université Laval.

Bone marrow transplantation. Recipient mice were exposed to 10 gray total-body irradiation using a cobalt-60 source. This dose was administered in two equal fractions and $3 \mathrm{hr}$ apart to minimize gastrointestinal toxicity. Approximately $24 \mathrm{hr}$ later, the animals were injected via a tail vein with $5 \times 10^{6}$ bone marrow cells freshly collected from GFP mice. The cells were aseptically harvested by flushing femurs with Dulbecco's PBS containing $2 \%$ fetal bovine serum (DPBS-FBS) using a syringe with a 25 ga needle. The samples were combined, centrifuged, and passed through a 25 ga needle and then filtered through a $40 \mu \mathrm{m}$ nylon mesh (Becton Dickinson, Cockeysville, MD). Recovered cells were resuspended in DPBS-FBS at a concentration of $5 \times 10^{6}$ viable nucleated cells per $300 \mu \mathrm{l}$. Irradiated mice transplanted with this suspension were housed in autoclaved cages and treated with antibiotics (Sulfatrim; $175 \mathrm{mg} / 250 \mathrm{ml}$ of drinking water given for $3 \mathrm{~d}$ before and 4 weeks after irradiation).

Aspiration lesion of the cerebral cortex. Five months after transplantation, a group of mice was anesthetized and immobilized in a stereotaxic frame. A midline incision was made on the scalp, followed by a circular craniotomy (diameter, $\sim 2 \mathrm{~mm}$ ) over the right hemisphere, $2 \mathrm{~mm}$ lateral and caudal from bregma. After removal of the dura mater, the underlying cortex was aspirated down to the dorsal corpus callosum, and the cavity (diameter, $\sim 1 \mathrm{~mm}$ ) was packed with Gelfoam soaked in sterile nonpyrogenic saline. The animals were killed 1 month after surgery.

Bromodeoxyuridine administration. Bromodeoxyuridine (BrdU) (Sigma, St. Louis, MO) was dissolved in saline at a concentration of $10 \mu \mathrm{g} / \mu \mathrm{l}$ and filtered at $0.2 \mu \mathrm{m}$. Mice were injected twice with $\operatorname{BrdU}(100 \mu \mathrm{g} / \mathrm{gm})$ at $2 \mathrm{hr}$ intervals and perfused $2 \mathrm{hr}$ after the final injection. This paradigm was designed to label a maximal number of dividing cells before the completion of the G2 plus M phase of the cell cycle, which has been estimated at $\sim 4.5 \mathrm{hr}$ for adult neural progenitor cells (Cameron and McKay, 2001), whereas circulating hematopoietic stem cells are quiescent (Uchida et al., 1997). Consequently, BrdU-positive cells observed in the brain under these conditions are assumed to have been labeled as a consequence of local proliferation.

Tissue processing. The animals were anesthetized and transcardially perfused with $10 \mathrm{ml}$ of saline containing $10 \mathrm{U} / \mathrm{ml}$ of heparin, followed by ice-cold $4 \%$ paraformaldehyde in phosphate buffer, $\mathrm{pH}$ 7.4, over $10 \mathrm{~min}$. Their brains were removed and postfixed for $5 \mathrm{hr}$ at $4^{\circ} \mathrm{C}$ and then cryoprotected overnight in $50 \mathrm{~mm}$ potassium PBS (KPBS) supplemented with $20 \%$ sucrose. Sections through the entire brain were cut at $30 \mu \mathrm{m}$ using a freezing microtome. Series of sections were collected in cryoprotectant (30\% ethylene glycol, $20 \%$ glycerol, 50 mm sodium phosphate buffer, $\mathrm{pH}$ 7.4) and stored at $-20^{\circ} \mathrm{C}$ until histological analysis.

BrdU unmasking. To allow for detection of BrdU-labeled cells (see immunofluorescence), sections were pretreated for $30 \mathrm{~min}$ in $2 \mathrm{~N} \mathrm{HCl}$ at $37^{\circ} \mathrm{C}$ to denature DNA, followed by $10 \mathrm{~min}$ in $100 \mathrm{~mm}$ sodium borate, $\mathrm{pH}$ 8.5 , to neutralize residual acid. BrdU pretreatment and immunolabeling were performed after staining for GFP.

Immunoperoxidase. Free-floating sections were treated with $0.3 \%$ $\mathrm{H} 2 \mathrm{O} 2$ for $30 \mathrm{~min}$ to inhibit endogenous peroxidase activity. Background staining was blocked by using an avidin-biotin-blocking kit, according to the manufacturer protocol (Vector Laboratories, Burlingame, CA), as well as by incubating the sections for $30 \mathrm{~min}$ in KPBS containing $5 \%$ goat serum and $0.4 \%$ Triton X-100. Using the same buffer solution, the sections were then incubated overnight at $4^{\circ} \mathrm{C}$ in primary antiserum (rabbit anti-GFP; 1:2000; Chemicon, Temecula, CA), followed by incubation for $2 \mathrm{hr}$ at room temperature in corresponding biotinylated goat secondary antiserum (1:300; Jackson ImmunoResearch, West Grove, PA). Staining was developed for 5-7 min in nickel-DAB solution (2.5\% nickel ammonium sulfate, $100 \mathrm{~mm}$ sodium acetate, $0.5 \mathrm{mg} / \mathrm{ml}$ diaminobenzidine, $2 \mathrm{mg} / \mathrm{ml}$ $\beta$-D(+)-glucose, $0.4 \mathrm{mg} / \mathrm{ml}$ ammonium chloride, $1 \mu \mathrm{l} / \mathrm{ml}$ glucose oxidase; Sigma). Each of the above steps was followed by four 5 min rinses in KPBS. The sections were mounted onto gelatin-coated slides and then dehydrated and coverslipped with DPX (a mixture of distyrene, tricresyl phosphate, and xylene; Electron Microscopy Sciences, Fort Washington, PA).

Immunofluorescence. Free-floating sections were incubated for $30 \mathrm{~min}$ in KPBS containing 5\% goat serum and $0.4 \%$ Triton X-100. Using the same buffer solution, the sections were then incubated overnight at $4^{\circ} \mathrm{C}$ in primary antibody [polyclonal rabbit anti-GFAP, 1:500 (Chemicon); monoclonal mouse anti-neuronal nuclei (NeuN), 1:500; polyclonal rabbit anti-neuronal class III $\beta$-tubulin (TuJ1), 1:500 (Covance, Richmond, CA); monoclonal rat anti-BrdU, 1:1000 (Accurate Chemicals, Westbury, NY); monoclonal rat anti-CD31, anti-Sca-1, and anti-CD45, 1:500 (PharMingen, San Diego, CA); polyclonal rabbit anti-ionized calciumbinding adapter molecule 1 (Iba1) (provided by Dr. S. Kohsaka, National Institute of Neuroscience, Japan), 1:750]. The sections were then transferred for $2 \mathrm{hr}$ at room temperature to solutions of fluorochromeconjugated goat secondary antisera (1:300; highly cross-absorbed antimouse Alexa 488, anti-rat Alexa 546, anti-rabbit Alexa 546 and 633; Molecular Probes, Eugene, OR). Each of the above steps was followed by four $5 \mathrm{~min}$ rinses in KPBS. The sections were mounted onto gelatincoated slides, counterstained with $2 \mu \mathrm{g} / \mathrm{ml}$ of diamidinophenylindole (DAPI; Molecular Probes) for $1 \mathrm{~min}$, rinsed in water, and coverslipped with antifade medium composed of $96 \mathrm{~mm}$ Tris- $\mathrm{HCl}, \mathrm{pH} 8.0,24 \%(\mathrm{w} / \mathrm{v})$ glycerol, $9.6 \%$ polyvinylalcohol, and $2.5 \%$ diazabicyclooctane (Sigma).

Fluoro-jade staining. Fluoro-jade is an anionic fluorescein derivative used to selectively stain degenerating neurons (Schmued et al., 1997). Brain sections were mounted onto gelatin and poly-L-lysine-coated slides. When fully dried, the slides were immersed in $100 \%$ ethanol for 3 min, followed by $70 \%$ ethanol, $50 \%$ ethanol, and distilled water for $1 \mathrm{~min}$ each. The slides were then transferred to a solution of $0.06 \%$ potassium permanganate for $10 \mathrm{~min}$ to block background staining. After an additional rinse in water, the sections were stained for $20 \mathrm{~min}$ in $0.004 \%$ Fluoro-jade B (Histochem, Jefferson, AR), 0.0002\% DAPI, and $0.1 \%$ acetic acid. The slides were rinsed in water three times for $1 \mathrm{~min}$, dried, soaked in xylene, and coverslipped with DPX.

Light microscopy and quantification. Quantitative analyses were performed by an observer who was blind to the treatment status of the material. To evaluate cell frequency, every 12 th section from the olfactory bulb to the brainstem was analyzed for each animal by epifluorescence microscopy (BX-61; Olympus Optical, Tokyo, Japan) with 20 and $60 \times$ oil objectives. The number of nuclear profiles of GFP-labeled cells was counted in select brain regions. The total number of GFP-positive cells was then estimated by multiplying the number of profiles by 12 and applying Abercrombie's correction (Abercrombie, 1946). Although it is not an unbiased estimate of the absolute cell numbers, this method permits a meaningful relative comparison of cells exhibiting various phenotypes. For cell phenotyping, at least 90 cells of each category per animal were analyzed for colocalization with cell type-specific markers using a Fluoview confocal microscope (Olympus Optical) and a $100 \times$ oil objective. The length and nuclear diameter of 30 cells per animal for each cellular type were measured on DAPI-counterstained sections with the Fluoview software (Olympus Optical) using the line selection tool. To evaluate Ibal fluorescence intensity over the surface of elongated and microglial cells, mid-cell section confocal images (thickness, $6 \mu \mathrm{m}$ ) were analyzed with NIH Image 1.62. The contour of at least 20 cells per cellular type was traced with the selection tool, and the mean optical intensity of that area was recorded. This value was subtracted from an average of three background measurements obtained with the round selection tool of a fixed dimension $(24 \times 24$ pixels $)$. Data were analyzed by Student's unpaired $t$ test. Confocal images were acquired with 20 and $100 \times$ oil objectives by sequential scanning using a two-frame Kalman filter and a 


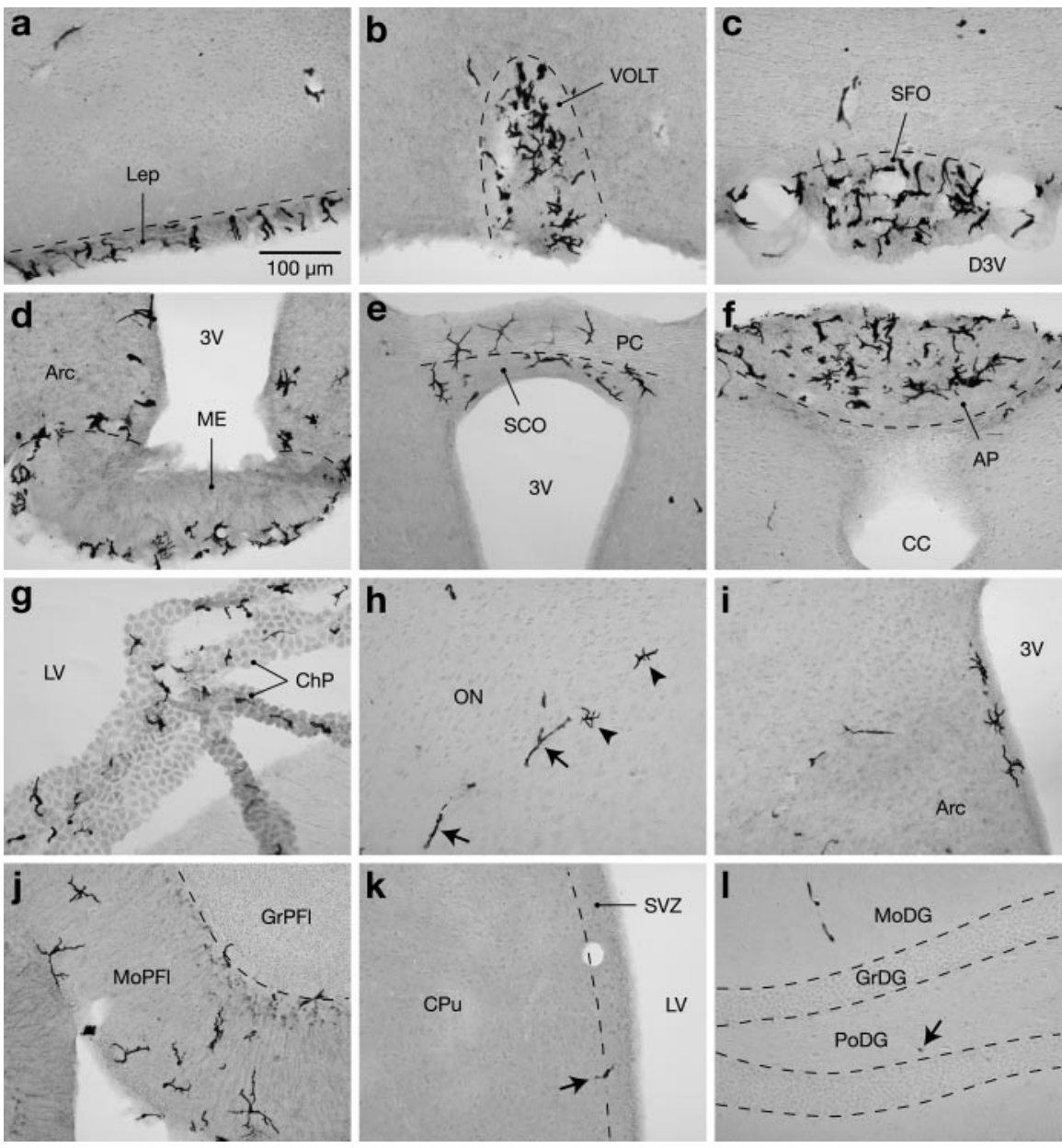

Figure 1. Distribution of donor-derived cells in brains of chimeric mice 3 months after transplantation. $a-g$, Immunoperoxidase labeling for GFP revealed many microglia-like cells in the leptomeninges $(a)$ and circumventricular organs, including the vascular organ of the lamina terminalis $(b)$, subfornical organ $(c)$, median eminence $(d)$, subcommissural organ $(e)$, area postrema $(f)$, and choroid plexus $(g)$. $h$, Positive cells of different morphologies were also found in regions protected by the bloodbrain barrier, such as elongated cells (arrows) and ramified cells (arrowheads) in the olfactory nucleus. Although elongated cells were widely distributed throughout the brain, the ramified cells were more frequently observed in the vicinity of the ventricles $(d, e, i)$ or within the molecular layer of the cerebellum ( $j)$. GFP-labeled cells (arrows) were infrequent in neurogenic areas, such as the subventricular $(k)$ and hippocampal subgranular ( $I$ ) zones. $3 \mathrm{~V}$, Third ventricle; AP, area postrema; Arc, arcuate hypothalamic nucleus; CC, central canal; ChP, choroid plexus; CPu, caudate putamen; D3V, dorsal third ventricle; GrDG, granular layer of the dentate gyrus; GrPfl, granular layer of the paraflocculus; Lep, leptomeninges; LV, lateral ventricle; ME, median eminence; MoDG, molecular layer of the dentate gyrus; $\mathrm{MoPfl}$, molecular layer of the paraflocculus; $\mathrm{ON}$, olfactory nucleus; $\mathrm{PC}$, posterior commissure; PoDG, polymorphic layer of the dentate gyrus; $\mathrm{SCO}$, subcommissural organ; SFO, subfornical organ; SVZ, subventricular zone; VOLT, vascular organ of the lamina terminalis. Scale bar, $100 \mu \mathrm{m}$.

$z$-separation of $0.25 \mu \mathrm{m}$. The images were processed with Adobe Photoshop (Adobe Systems, San Jose, CA) to enhance contrast and sharpness and then assembled using Adobe Illustrator (Adobe Systems).

Immunoelectron microscopy. To examine in detail the fine structure and cellular relationships of donor-derived cells, brains from groups of mice that were irradiated-transplanted 6 or 12 months earlier were prepared for pre-embedding immunoperoxidase localization of GFP and examined at the ultrastructural level. Mice were anesthetized and perfused with saline, followed by $25 \mathrm{ml}$ of $3.75 \%$ acrolein and $2 \%$ paraformaldehyde and then $200 \mathrm{ml}$ of $2 \%$ paraformaldehyde, all in $100 \mathrm{~mm}$ phosphate buffer. Blocks of select regions were sectioned on a vibratome at $50 \mu \mathrm{m}$ and collected in KPBS. Immunoperoxidase localization of GFP was performed as described above, except that tissue was never exposed to detergent. Sections were dehydrated in ethanol and propylene oxide and then flat-embedded in Spurr's epoxy resin between glass slides coated with liquid release agent (Electron Microscopy Sciences). Thin sections through regions of interest were collected and stained with uranyl acetate and lead citrate and then examined on a Jeol (Peabody, MA)
100 CX II transmission electron microscope. Images were collected as TIFF files using a MegaView III digital camera (SoftImaging System, Lakewood, CO) and edited in Photoshop (Adobe Systems).

\section{Results}

\section{General observations}

To examine the distribution of bone marrow-derived cells in the adult brain, we transplanted lethally irradiated mice with bone marrow cells freshly collected from isogenic transgenic mice that expressed GFP in all of their cells except erythrocytes. Groups of animals were killed 1, 3, 6, and 12 months after this intervention, and series of sections encompassing the entire brain were processed for immunoperoxidase localization of GFP. Labeled cells were seen predominantly in structures outside the blood-brain barrier, including the leptomeninges and circumventricular organs, with most exhibiting a microglia-like morphology (Fig. 1 $a-g$ ). Positive cells of varying shapes and sizes were also detected in all regions of the white and gray matter (Fig. $1 h-l)$. The vast majority of these cells was not distributed uniformly but were instead associated with blood vessels of all calibers, particularly those that radially penetrate the cerebral cortex and those that irrigate the molecular and lacunosum moleculare layers of the hippocampal dentate gyrus and Ammon's horn, respectively. GFPlabeled cells were rare in neurogenic areas, including the subventricular and hippocampal subgranular zones, and none that were detected in these regions displayed a typical neuronal morphology (Fig. $1 k-l$ ). The distribution of GFPlabeled cells was comparable across individual animals, but their frequency clearly increased with time and varied among anatomical regions. To evaluate the specificity of immunolabeling, we analyzed in parallel brain sections of irradiated mice infused with bone marrow cells harvested from $\beta$-galactosidase transgenic mice. As expected, no GFP staining was detected in any cerebral region. Thus, new cells are generated in the mature brain via the recruitment of circulating bone marrow-derived precursors. This phenomenon is not a consequence of radiation-induced neuronal death because mice that were killed 1, 3, or $6 \mathrm{~d}$ after lethal radiation exposure did not exhibit any cells positively labeled with Fluoro-jade, a selective marker for degenerating neurons (Schmued et al., 1997).

We next attempted to determine the phenotype of donorderived cells found throughout the brain. Series of sections were processed for multiple immunofluorescence detection of GFP, proliferation, and cell type-specific markers, counterstained with the nuclear dye DAPI, and analyzed by epifluorescence or confocal microscopy. In regions lacking a blood-brain barrier, $87 \pm$ $2 \%$ (subfornical organ) to $97 \pm 5 \%$ (leptomeninges) of GFP- 

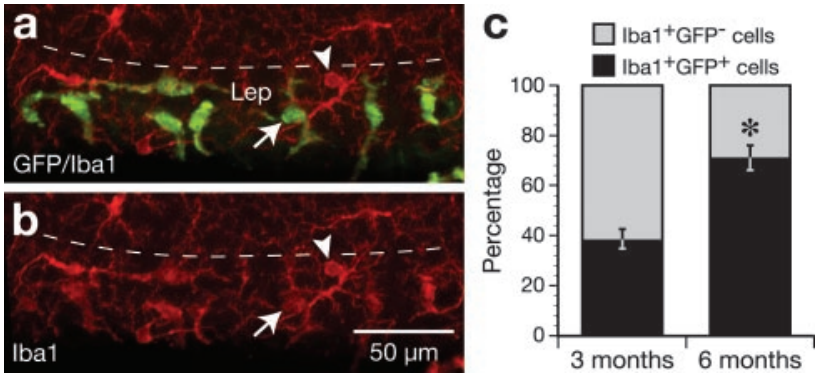

Figure 2. Phenotype of donor-derived cells in the leptomeninges (Lep) revealed by multiple immunofluorescence labeling. a, Confocal photomicrograph showing examples of lba1immunoreactive macrophages (red) that were either positive (green, arrow) or negative (arrowhead) for GFP. b, Same image as in a without GFP labeling. c, Quantification indicates a 1.8-fold increase in the number of donor-derived leptomeningeal macrophages between 3 and 6 months after transplantation. Data are expressed as mean \pm SD. ${ }^{*} p<0.0001$. Scale bar, $50 \mu \mathrm{m}$.

positive cells were immunoreactive for the monocytic marker Iba1, a calcium-binding protein involved in membrane ruffling and phagocytosis (Ito et al., 1998; Kanazawa et al., 2002). For example, at the level of the leptomeninges, we estimated that $39 \pm$ $2 \%$ of Iba1-expressing cells were stained positively for GFP at 3 months after transplantation, a ratio that increased significantly to $71 \pm 3 \%$ after 6 months $(p<0.0001$ ) (Fig. 2). This suggests that the population of leptomeningeal macrophages is likely to be completely replaced within less than a year. In areas protected by the blood-brain barrier, we also detected thousands of donorderived cells, which could be classified into five distinct categories on the basis of their morphology. From the shortest to the longest, these were termed round, rod-shaped, amoeboid, stellate, and elongated cells (Fig. 3). Phenotypic characterization and quantification of each of these cell types is presented in Tables 1 and 2. Overall, none of the GFP-positive cells expressed the astrocytic marker GFAP or the neuronal antigens NeuN and Tuj1. In contrast, they were all reactive for the leukocyte common antigen CD 45, and most of them expressed Ibal in proportions that varied from 92 to $89 \%$ in the cerebral cortex at 3 and 6 months after irradiation, respectively (Table 2) (sum of Iba1-labeled round, amoeboid, elongated, and stellate cells). Immunostaining with the endothelial cell markers CD31 or Sca-1 revealed that nearly all donor-derived cells were closely associated with blood vessels. Throughout the cerebral cortex, only $0.08-0.25 \%$ of GFP-positive were deeply implanted in the parenchyma, exhibiting no apparent association with vascular elements (Table 2) (sum of stellate and round cells located outside blood vessels). Furthermore, administration of a $4 \mathrm{hr}$ pulse of BrdU before killing was successful in labeling approximately four donor-derived cells per series of sections for each animal, corresponding to an extrapolated total of 35 cells per brain, or $1 \%$ of the population of BrdU-positive cells. In sum, the results indicate that bone marrow-derived cells preserve their hematopoietic identity after entering the brain, and that only a minor fraction of them manifest the ability to proliferate in this paradigm. Specific observations for each cell category are reported below.

\section{Elongated cells}

Among all GFP-positive cells, those exhibiting an elongated morphology were most abundant (Table 2). For example, in the cerebral cortex, these cells represented $\sim 69 \%$ of the total number of GFP-positive cells at 6 months after irradiation, with an average of $\sim 80$ cells per cortical section. Some elongated cells displayed neuron-like morphological features because they were bipolar or
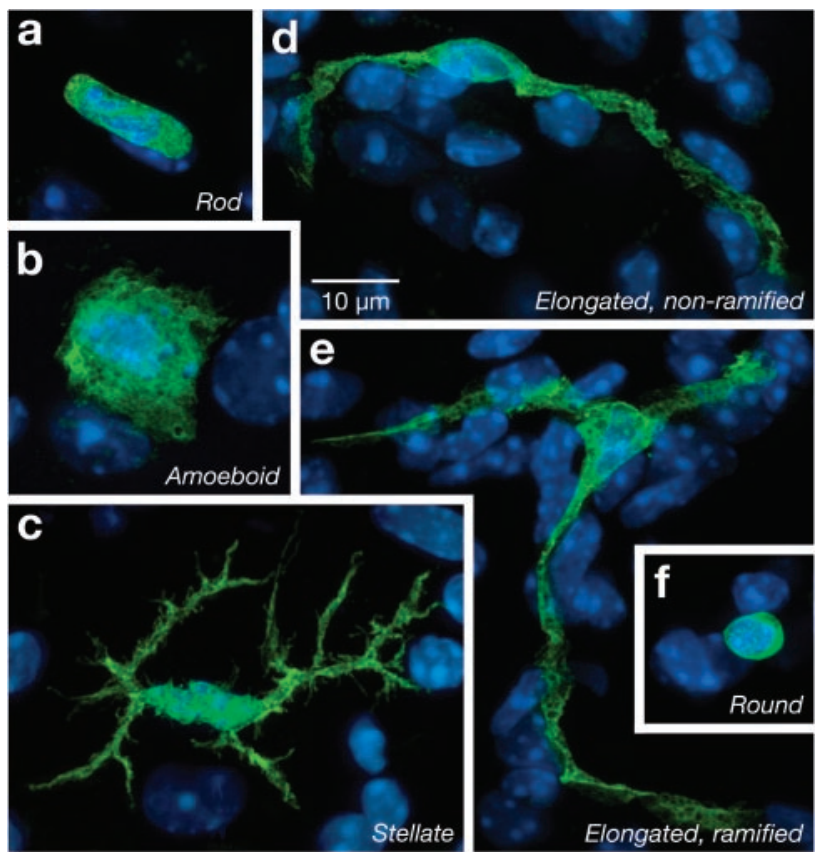

Figure 3. Morphology of donor-derived cells found in brain regions protected by the bloodbrain barrier. These confocal images show representative examples of GFP-labeled cells (green) counterstained with DAPI (blue). $a$, A rod cell in the cerebral cortex. b, An amoeboid cell associated with a large blood vessel in the thalamus. c, A stellate cell in the cerebellum. $d, A$ bipolar elongated cell in the lateral preoptic area. e, A tripolar elongated cell in the cerebral cortex. $f, A$ round cell in the caudate-putamen. Scale bar, $10 \mu \mathrm{m}$.

tripolar, with processes spanning $>100 \mu \mathrm{m}$, and their surfaces were devoid of spicules (Figs. 3d,e, 4). However, elongated cells expressed neither NeuN (Fig. 4a-d) nor TuJ1 (data not shown), and all stained positively for Ibal (Fig. $4 e-h, n, o$ ). Of interest is the observation that estimates of Iba1 levels within elongated cells were on average 2.9 times lower $(p<0.0001)$ than those in parenchymal microglia (Fig. 4o,p), suggesting some functional differentiation between the cell types. To assess the position occupied by elongated cells relative to the blood-brain barrier, additional sections were immunostained for CD31. All elongated cells were intimately associated with the vasculature, including capillaries and vessels of larger caliber (Fig. $4 i-n)$. The cells contacted the vascular wall, extended long projections parallel to the long axis of the vessel, and resided on the parenchymal side but never within the lumen. Similar observations were obtained when visualizing the endothelium using a Sca-1 antiserum. Ultrastructural analyses of the brain parenchyma from animals killed at 6 or 12 months after transplantation confirmed a nearly exclusive association of GFP-immunolabeled elements with the cerebral vasculature. Profiles of labeled perikarya varied in shape from elongated to round to multipolar, with processes extending as far as $100 \mu \mathrm{m}$. Labeled elements associated with the vasculature were always segregated by a basement membrane from endothelia and pericytes that comprise the vascular wall and from the parenchyma by the glia limitans (Fig. 4q-s). Together, the results indicate that elongated cells belong to a subset of macrophages termed perivascular cells, which are not integral components of the vascular wall (situated instead in the perivascular space) or involved directly in executing barrier-related functions.

\section{Amoeboid cells}

Amoeboid cells, the second most abundant type of donorderived cells, were seen in the cerebral cortex at 6 months after 
Table 1. Characteristics of bone marrow-derived cells in brains of adult chimeric mice as visualized by multiple immunolabeling and confocal microscopy

\begin{tabular}{|c|c|c|c|c|c|}
\hline & \multicolumn{5}{|l|}{ GFP-positive cells } \\
\hline & Round & Rod & Amoeboid & Elongated & Stellate \\
\hline \multicolumn{6}{|l|}{ Morphology } \\
\hline Cell & $\begin{array}{l}\text { Round or oval, sparse cyto- } \\
\text { plasm, with or without } \\
\text { spicules }\end{array}$ & $\begin{array}{l}\text { Rod-shaped, sparse } \\
\text { cytoplasm, smooth } \\
\text { contour }\end{array}$ & $\begin{array}{l}\text { Amoeboid, extensive cyto- } \\
\text { plasm, with or without } \\
\text { small processes }\end{array}$ & $\begin{array}{l}\text { Elongated, sparse cytoplasm, } \\
\text { irregular contour, bipolar or } \\
\text { tripolar }\end{array}$ & $\begin{array}{l}\text { Small cell body with many } \\
\text { primary and secondary } \\
\text { ramifications }\end{array}$ \\
\hline Nucleus & Round or oval & Rod-shaped & Round or oval & Round, oval or rod-shaped & Round or oval \\
\hline \multicolumn{6}{|c|}{ Size $(\mu \mathrm{m} \pm \mathrm{SD})$} \\
\hline Cell $^{a}$ & $8 \pm 0.9$ & $17.7 \pm 2.9$ & $26.8 \pm 9.1$ & $72 \pm 16.3$ & $59.9 \pm 9$ \\
\hline Nucleus & $6.7 \pm 0.7$ & $11.7 \pm 1.5$ & $9.8 \pm 2.1$ & $12 \pm 2.8$ & $9.6 \pm 2$ \\
\hline \multicolumn{6}{|c|}{ Immunoreactivity } \\
\hline BrdU & - & - or + (rare) & - or + (rare) & - & - \\
\hline CD31 & - or + & - & - & - & - \\
\hline CD45 & + (strong) & + (strong) & + (weak) & + (weak) & + (weak) \\
\hline GFAP & - & - & - & - & - \\
\hline Iba1 & - or + & - & + (weak) & + (weak) & + (strong) \\
\hline NeuN & $-^{b}$ & - & - & - & - \\
\hline Tuj1 & - & - & - & - & - \\
\hline Location & $\begin{array}{l}\text { Inside blood vessels or } \\
\text { within parenchyma }\end{array}$ & Inside blood vessels & $\begin{array}{l}\text { Associated with outer wall } \\
\text { of large blood vessels }\end{array}$ & $\begin{array}{l}\text { Associated with outer wall of } \\
\text { blood vessels of all calibers }\end{array}$ & $\begin{array}{l}\text { Parenchyma, preferentially } \\
\text { in cerebellum }\end{array}$ \\
\hline
\end{tabular}

${ }^{a}$ Cell length includes processes extending beyond the perinuclear cytoplasm.

${ }^{b}$ Rare round cells located inside blood vessels were found unspecifically labeled for NeuN.

Table 2. Frequency of GFP-positive bone marrow-derived cells in brain regions of adult chimeric mice 3 or 6 months after transplantation

\begin{tabular}{|c|c|c|c|c|c|c|c|c|}
\hline & \multicolumn{8}{|c|}{ Estimated cell number (percentage relative to the total population of GFP-positive cells in the corresponding area) } \\
\hline & \multicolumn{4}{|l|}{ Round } & \multirow[b]{2}{*}{ Rod } & \multirow[b]{2}{*}{ Amoeboid } & \multirow[b]{2}{*}{ Elongated } & \multirow[b]{2}{*}{ Stellate } \\
\hline & $\mathrm{BV}^{+} \mathrm{Iba}^{+}$ & $\mathrm{BV}^{+} \mathrm{Iba} 1^{-}$ & $\mathrm{BV}^{-} \mathrm{lba} 1^{+}$ & $\mathrm{BV}^{-} \mathrm{Iba} 1^{-}$ & & & & \\
\hline \multicolumn{9}{|c|}{ Cerebral cortex } \\
\hline 3 months & $235(1.89)$ & 191 (1.54) & $5(0.04)$ & $5(0.04)$ & 807 (6.49) & 1835 (14.76) & 9354 (75.24) & 0 \\
\hline 6 months & $125(0.65)$ & $213(1.10)$ & $15(0.08)$ & $32(0.17)$ & $1882(9.74)^{*}$ & $3695(19.13)$ & $13353(69.13)$ & 0 \\
\hline \multicolumn{9}{|c|}{ Caudoputamen } \\
\hline 3 months & 59 & 49 & 0 & 0 & 212 & ND & ND & 0 \\
\hline 6 months & 54 & 29 & 0 & 5 & 317 & ND & ND & 0 \\
\hline \multicolumn{9}{|c|}{ Corpus callosum } \\
\hline 3 months & 0 & 0 & 0 & 0 & 39 & ND & ND & 0 \\
\hline 6 months & 17 & 5 & 0 & 17 & 82 & ND & ND & 0 \\
\hline \multicolumn{9}{|l|}{ Hippocampus } \\
\hline 3 months & 15 & 10 & 0 & 5 & 99 & ND & ND & 0 \\
\hline 6 months & 20 & 37 & 2 & 10 & $168^{*}$ & ND & ND & 0 \\
\hline \multicolumn{9}{|l|}{ Hypothalamus } \\
\hline 3 months & 34 & 20 & 15 & 0 & 22 & ND & ND & 0 \\
\hline 6 months & 39 & 61 & 0 & 15 & 69 & ND & ND & 11 \\
\hline \multicolumn{9}{|l|}{ Thalamus } \\
\hline 3 months & 44 & 78 & 5 & 5 & 112 & ND & ND & 0 \\
\hline 6 months & 27 & 54 & 0 & 10 & 278 & ND & ND & 2 \\
\hline \multicolumn{9}{|l|}{ Cerebellum } \\
\hline 3 months & 34 & 15 & 5 & 39 & 147 & ND & ND & 27 \\
\hline 6 months & 20 & 29 & 7 & 44 & $364^{*}$ & ND & ND & 170 \\
\hline
\end{tabular}

$\mathrm{BV}^{+}$, Inside blood vessels; $\mathrm{BV}^{-}$, outside blood vessels; $\mathrm{ND}$, not determined. Asterisk indicates significant difference between both time groups $(p<0.01 ; n=4)$.

transplantation with a frequency of $\sim 29$ cells per section, comprising $19 \%$ of the GFP-labeled population (Table 2). Multiple labeling and three-dimensional reconstruction of confocal images showed that these cells were flat and contained an extensive perinuclear cytoplasm, with some extending small projections (Figs. $3 b, 5)$. Amoeboid cells were phenotypically similar to elongated cells and occupied a comparable position relative to the endothelium (Fig. 5). However, in contrast to elongated cells, the amoeboid cells were not associated with capillaries but only with vessels of larger caliber (Fig. 5j). Moreover, amoeboid cells were the principal donor-derived cells occasionally found to be labeled with BrdU in regions invested with a blood-brain barrier (Fig.
$5 k-m)$. Therefore, amoeboid cells constitute another subset of perivascular cells, differing from elongated cells on morphology, distribution, and proliferation potential.

\section{Rod-shaped cells}

Rod-shaped cells (Table 2; Figs. 3a, 6) constituted 9.7\% of the GFP-labeled cortical population at 6 months after irradiation, with a mean occurrence of 11 cells per cortical section. These cells did not express detectable levels of Ibal and were intimately associated with endothelial elements exhibiting CD31 or Sca-1 immunoreactivity (Fig. $6 a-l$ ). Because these two latter antigens were uniformly distributed on the surface of blood vessels, indi- 
vidual endothelial cells could not be distinguished, and it was therefore impossible to determine whether rod cells conformed to endothelial cells or another cell type enwrapped by Sca-1-CD31-positive endothelia. To rule out the possibility that rod cells were endothelial cells, we stained sections with CD45 and found that essentially all rod cells expressed this leukocyte marker (Fig. $6 e-h)$. Curiously, whereas the majority of rod cells were individually scattered and exhibited the morphology shown in Figure 6i, $\sim 15 \pm 3 \%$ of rod-shaped cells appeared to be in a process of sprouting (Fig. $6 q-v$ ), with some $(0.1 \pm 0.4 \%)$ occurring as doublets (Fig. $6 w$ ). Although the number of rodshaped cells increased significantly from 3 to 6 months $(p<0.01)$ (Table 2$)$, the proportion of doublets or sprouted cells remained unchanged (Fig. 6x). To evaluate the capacity of rod-shaped cells to divide, a total of 1424 BrdU-labeled cells were phenotyped, but only one rod cell labeled positively for the proliferation marker. Overall, the results indicate that rod-shaped cells comprise an undetermined type of leukocyte, apparently distinct from monocytic cells, which are associated with the luminal surface of blood vessels and rarely manifest the capacity to proliferate.

\section{Round cells}

In the cerebral cortex of animals killed 6 months after transplantation, an average 2.5 round cells was counted per section, which accounted for $2 \%$ of the GFP-positive population (Table 2; Figs. 3f, 7). Multiple immunolabeling for Iba1 and CD31 allowed for the classification of round cells into four subgroups, including those that did or did not costain for Ibal and were located within or outside blood vessels. For example, $87.5 \%$ of the round cells in the cortex resided within the vasculature, among which $37 \%$ expressed Ibal. The remaining fraction (i.e., those found in the parenchyma and not vessel-associated) represented $0.25 \%$ of the population of GFP-positive cells, and $32 \%$ of these were colabeled for Iba1. In other words, only $0.17 \%$ of all donor-derived cells found in the cortex $(\sim 32$ cells per animal) had traversed the blood-brain barrier and did not belong to the monocytic lineage. Furthermore, in every animal that was analyzed, a small number of round cells ( $<5$ per series of sections) was immunoreactive for NeuN (Fig. 7i-t). These cells were smaller than surrounding neurons and morphologically similar to some of the NeuN-positive bone marrow-derived cells described by Brazelton et al. (2000). However, additional characterization revealed that these cells were located within microvessels (Fig. $7 q-t)$, did not express Tuj1 (data not shown), and stained positively for CD45 (Fig. $7 u-x$ ), arguing against the possibility that the NeuN-positive donor-derived cells were neurons. As a negative control, we briefly incubated blood samples collected from
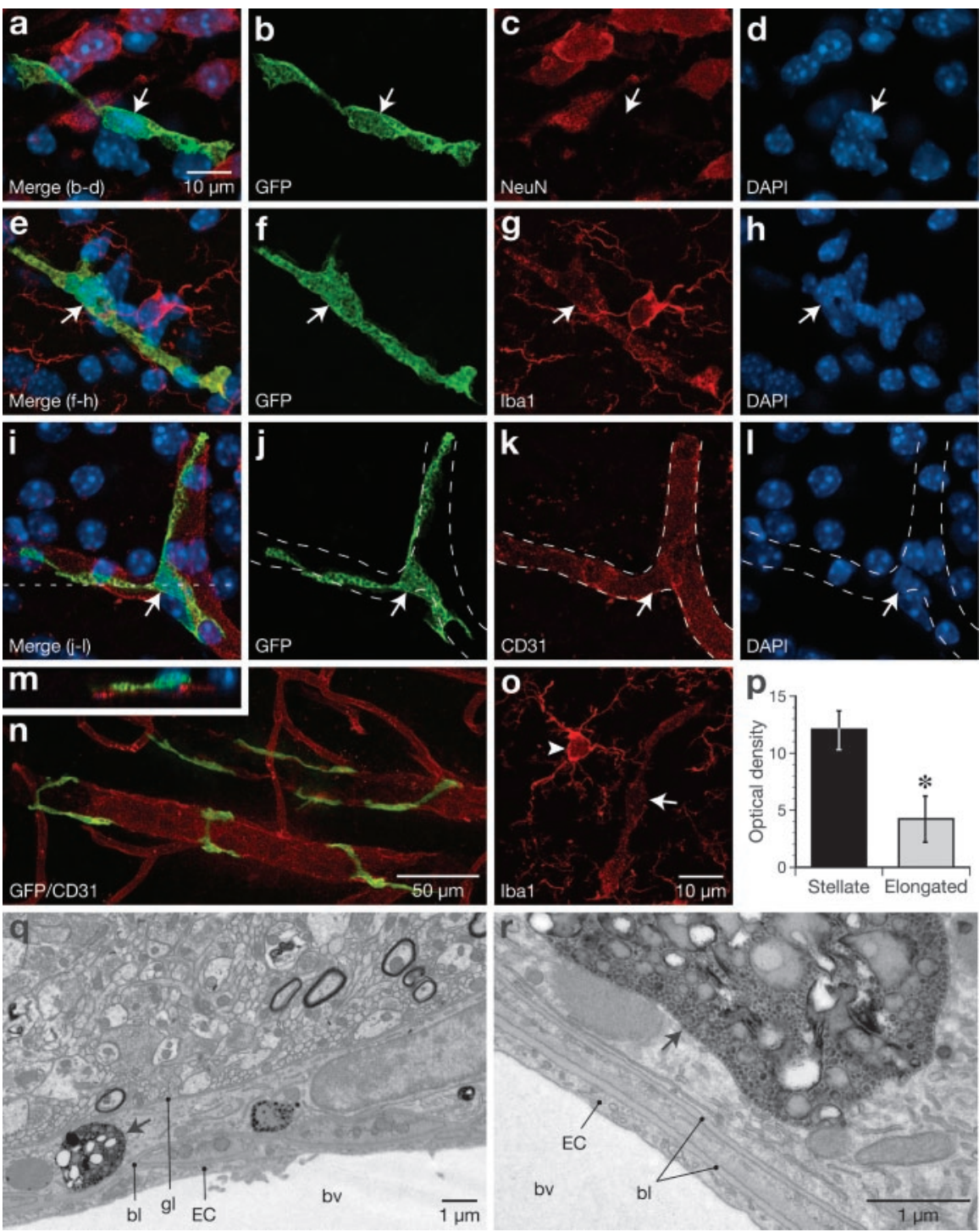

Figure 4. Phenotype of donor-derived cells with an elongated morphology. $a-n$, Confocal images showing GFP-labeled cells (green, arrows) counterstained with DAPI (blue) that were negative for NeuN ( $a-d$, cerebral cortex), positive for lba1 (e- $h$, $x$-z-plane of $i$ (dotted line) shows that the GFP-labeled cell is located on the blood vessel. 0 , Elongated cells (arrow) expressed lba1 levels that were on average 2.9 times lower than those produced by stellate cells (arrowhead) as revealed by fluorescence density blood vessels (bv) in the basal forebrain. Cellular profiles exhibiting GFP immunoreactivity (dark) were invariably situated within one basal lamina (bl). Scale bars: (in $a, 0) a-m, 0,10 \mu \mathrm{m} ; n, 50 \mu \mathrm{m} ; q, r, 1 \mu \mathrm{m}$.

GFP transgenic mice with the anti-mouse secondary antibody used to localize NeuN-immunoreactivity and found many positive cells, suggesting that the NeuN labeling of GFP-labeled cells observed in brain microvessels was nonspecific and most likely attributable to the presence of immunoglobulin-binding proteins on their surface. It should be noted that this cross-reacting secondary antibody was only used for this experiment and did not confound other aspects of the analysis. Thus, we conclude that round cells constitute a heterogeneous population of leukocytes, with some exhibiting the capacity to invade the parenchyma.

\section{Stellate cells}

Stellate cells exhibiting radial ramifications similar to resident microglia comprised the least numerous donor-derived cell type 

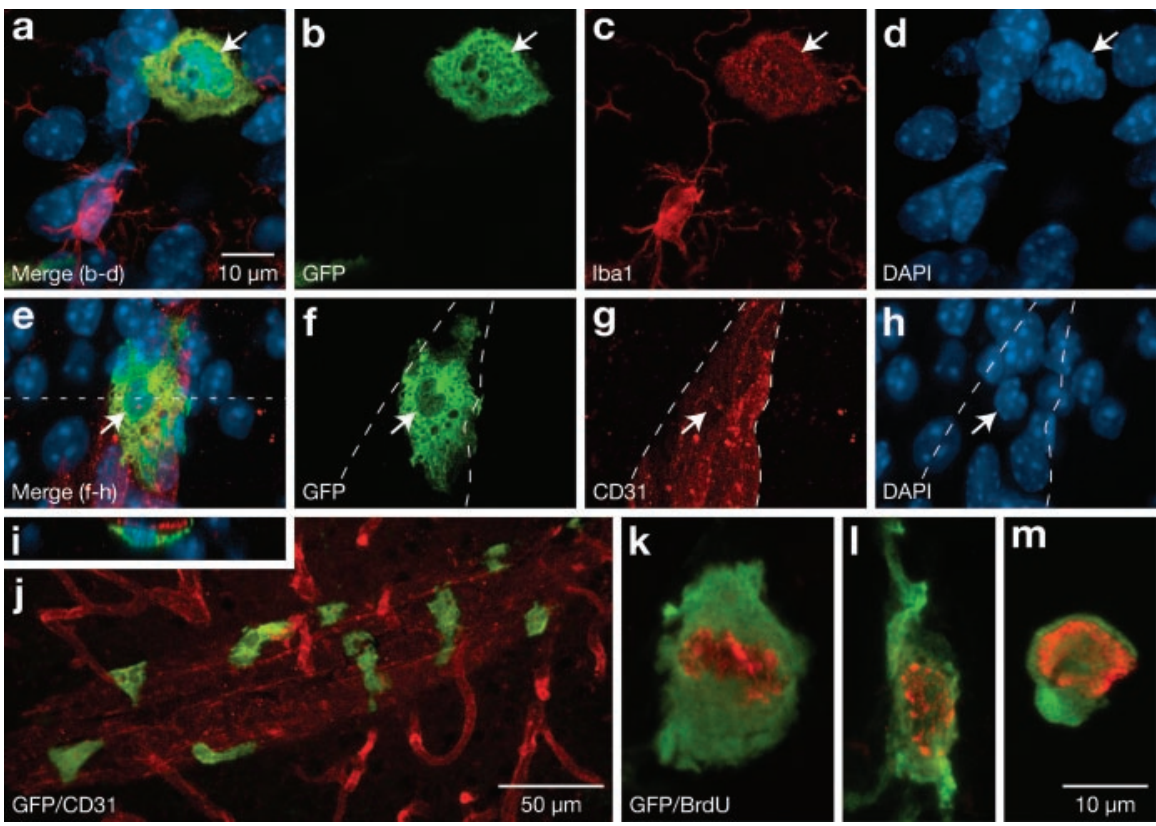

Figure 5. Phenotype of donor-derived cells with an amoeboid morphology. $a-h$, Confocal images showing GFP-labeled cells (green, arrows) counterstained with DAPI (blue) that were positive for lba1 ( $a-d$, thalamus) and intimately associated with larger blood vessels ( $e-h$, cerebral cortex). $i$, This reconstructed image corresponding to an $x-z$-plane of $e$ (dotted line) reveals that the GFP-labeled cell is located on the blood vessel. j, Examples of amoeboid cells associated with a large blood vessel in the cerebral cortex. $k-m$, Examples of amoeboid cells that stained positively for BrdU (red). Scale bars: (in $a$ ) $a-i, k-m, 10 \mu m ; j, 50 \mu m$.

seen in the brain (Table 2; Figs. $3 c, 8$ ). These cells were never detected in some regions, including the cerebral cortex, caudoputamen, and hippocampal formation. A few were observed in proximity to regions lacking a blood-brain barrier, such as the arcuate nucleus (Fig. 1d) or adjacent to the ventricular system (Fig. 1i). Rarely, small clusters of stellate cells were also encountered in the hypothalamus and thalamus. The only parenchymal region where stellate cells were reliably found was the cerebellum, in which they were always localized to the molecular layer and most abundantly in the paraflocculus (Fig. 1j). Immunohistological analyses confirmed the expectation that these cells expressed high levels of Iba1 (comparable with surrounding microglia) and were not associated with the vasculature (Fig. 8). Therefore, stellate cells correspond to newly formed parenchymal microglia that populate the brain in a region-specific manner.

\section{Recruitment of donor cells after injury}

To address the possibility that injury-induced molecular cues might direct circulating precursors into a neural or endothelial lineage, additional chimeric mice were subjected to an aspiration lesion of the cerebral cortex 5 months after transplantation and killed 4 weeks after surgery. Many GFP-labeled cells resembling each of the cell types described above were found in the region immediately surrounding the lesion but were not more numerous in the apparently healthy tissue proximal to this area, as compared with the contralateral side. Donor-derived cells recruited in response to injury were all positive for CD45, and $97 \pm$ $2 \%$ were immunostained for Ibal (Fig. 9). Thus, circulating precursors appear neither to transdifferentiate nor participate directly to vascular reorganization after a mechanical insult but rather give rise to macrophages that persist for a prolonged period at the lesion site.

\section{Discussion}

During embryogenesis, it is well known that certain cerebral cells derive from circulating precursors that originate in peripheral

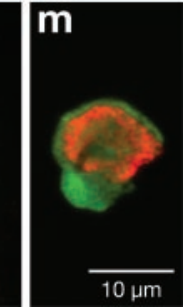

tissues. The extent to which this phenomenon persists into adulthood and precisely how it is manifested are questions that remain matters of intense debate. On the basis of morphological and phenotypic criteria, the present study demonstrates that bone marrow-derived cells access the mature brain in significant numbers but are not able to replenish the pool of neural stem cells destroyed by irradiation or differentiate into neurons, macroglia, or endothelia, even after a mechanical insult to the brain. Instead, they primarily give rise to different populations of macrophages that become integral components of the brain, with some retaining the capacity to divide. Only rarely do leukocytes other than those of the monocytic lineage penetrate the blood-brain barrier, questioning the ability of this population to patrol the neural milieu.

The present work is in agreement with recent reports supporting the concept that adult stem cells are endowed with a fixed and restricted capacity of multilineage differentiation (Castro et al., 2002; Wagers et al., 2002), and we provide a detailed characterization of all cell types that infiltrate the adult brain. Our results also exclude the possibility that nonhematopoietic stem-progenitor populations within bone marrow can generate neural cells in irradiated mice, a question left open by Wagers et al. (2002), who used highly purified hematopoietic stem cells in their transplantation studies. However, the present results contrast sharply with numerous observations that bone marrow-derived cells can assume neuronal, astroglial, or oligodendroglial characteristics in vivo (Eglitis and Mezey, 1997; Kopen et al., 1999; Brazelton et al., 2000; Mezey et al., 2000, 2003; Li et al., 2001; Lu et al., 2001; Nakano et al., 2001; Priller et al., 2001a; Akiyama et al., 2002; Bonilla et al., 2002; Corti et al., 2002; Zhao et al., 2002; Weimann et al., 2003). In many of these cases, we believe the discrepancy could be explained primarily by the use of unspecific and less sensitive histochemical methods or the lack of high-resolution (including three-dimensional) confocal analyses. For example, most infiltrating cells, as reported by Brazelton et al. (2000), expressing neuronal antigens are morphologically similar to our round, rod, elongated, and stellate cells and could have been labeled unspecifically because of the presence of immunoglobulin-binding proteins at their surface, as was the case with at least some round cells in the present study. In addition, because we observed in preliminary experiments that the Ibal antiserum affords greater sensitivity than other monocytic markers (e.g., F4/80, OX-42), it is possible that use of the latter in previous studies could have produced false negative results, particularly if perivascular cells express antigens at low levels, just as they exhibit reduced levels of Iba1. However, concerning the identification by other groups of bone marrow-derived cells exhibiting the characteristic morphology of cerebellar Purkinje neurons (Priller et al., 2001a; Wagers et al., 2002), our study did reproduce this observation, but we cannot categorically refute it. It should be noted that such cells seem to be extremely rare, and the question of whether their appearance is indicative of transdifferentiation, cell fusion, or experimental artifact remains to be determined. If circulating precursors can in fact give rise to neu- 
rons in the cerebellum and other regions not known to support neurogenesis, it would be perplexing that numerous studies, in which animals received multiple doses of BrdU over several days (a procedure that would label bone marrowderived precursors before their migration into brain), have not reported BrdUpositive neurons in these areas.

Many in vitro studies also reported the conversion of bone marrow cells into neurons (Ling et al., 1998; Sanchez-Ramos et al., 2000; Woodbury et al., 2000; Kohyama et al., 2001). These attempts do not provide undeniable proof of transdifferentiation because whole bone marrow extracts were used instead of purified or clonally derived stem cells. Indeed, such samples might be populated with neural stem cells, which have recently been discovered in the adult peripheral nervous system (Kruger et al., 2002) and might be contained in nerve fibers innervating the bones. $\mathrm{Al}$ though such contaminating cells may not express their ability to generate neural elements when infused into the blood, they could do so in vitro or if grafted into the brain.

It was recently demonstrated that bone marrow cells can spontaneously fuse with embryonic stem cells in coculture, raising the possibility that donor-derived cells may occasionally form hybridomas with recipient cells (Terada et al., 2002; Ying et al., 2002). However, as noted, such fusion events are rare in vitro and unlikely to occur on a large scale in vivo. Numerical chromosomal abnormalities elicit genomic instability leading to apoptosis or tumor development. The only normal cell types known to be capable of homologous fusion in vivo are myoblasts that form multinucleated muscle fibers (Taylor, 2002) and reactive macrophages that give rise to giant multinucleated phagocytes during immune reactions (Papadimitriou and Walters, 1979; Davis et al., 1994). In this study, we never observed large multinucleated cells that might be indicative of cell fusion. Indeed, morphometric analyses revealed that GFPpositive cells contain a single nucleus similar in appearance to those of surrounding cells and that varies in diameter from 6 to 12 $\mu \mathrm{m}$. However, we cannot rule out the possibility that rare fusion events between transplanted marrow-derived and recipient cells may occur in vivo, a phenomenon clearly worthy of additional investigation.

The formation of blood vessels can result from the complementary processes of vasculogenesis and angiogenesis. The former is defined by the recruitment of circulating endothelial precursors at the site of vascularization, whereas the latter involves the sprouting and proliferation of preexisting endothelia. During the early embryonic period, vasculogenesis is responsible for laying down a primitive vascular network, which is subsequently remodeled and expanded by angiogenesis. Angiogenesis is the predominant mechanism of blood vessel formation in the
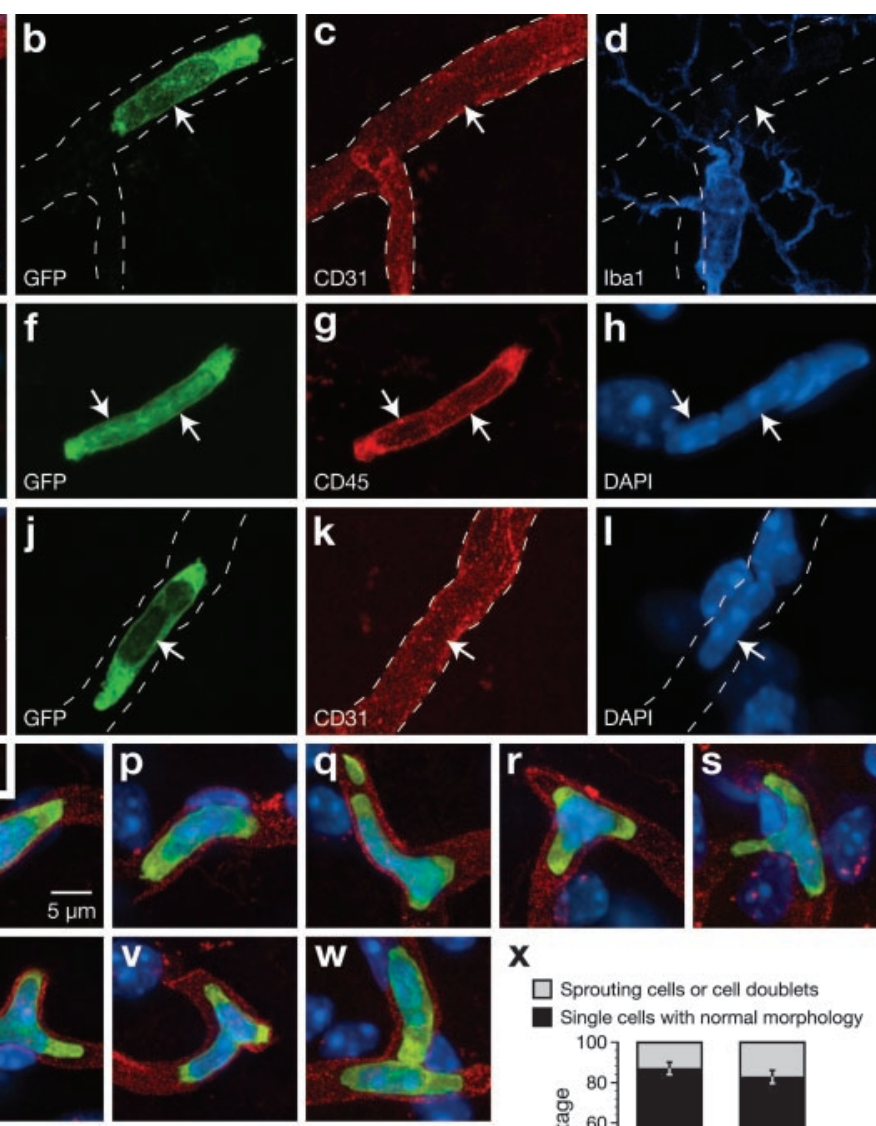

$\mathbf{X}$

$\square$ Sprouting cells or cell doublets Single cells with normal morphology

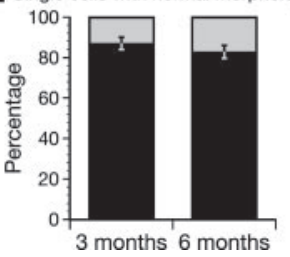

Division

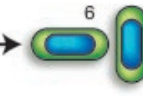

3 months 6 months

Figure 6. Phenotype of donor-derived cells with a rod-shaped morphology. $a-d$, Confocal images of a GFP-positive rod cell (arrows) that stained positively for CD45. $i-m$, A rod cell located inside a blood vessel. $m$, This reconstructed image corresponding $x-z$-plane of $i$ (dotted line) shows that the GFP-labeled cell is located within the microvessel. $n-p$, Rod cells of different sizes exhibiting characteristic morphology. $q-V$, Rod cells showing apparent sprouts of variable length and position. $W$, Rod cell population of individual (singly occurring-nonsprouting) rod cells did not change significantly between 3 and 6 months after transplantation. $y$, A hypothetical model for rod cell development in the adult mouse brain. Scale bar: $a-w, 5 \mu \mathrm{m}$.

adult, but the recruitment of circulating endothelial precursors derived from the bone marrow has been observed in peripheral organs after injury (Takahashi et al., 1999; Kalka et al., 2000; Kocher et al., 2001; Shintani et al., 2001). Zhang et al. (2002) recently attempted to demonstrate the persistence of vasculogenesis in the mature brain by transplanting irradiated mice with bone marrow cells expressing $\beta$-galactosidase under control of the Tie-2 promoter. They reported a recruitment of circulating endothelial precursors in the choroid plexus under basal conditions and increased vasculogenesis in infected areas after ischemia. Unfortunately, this experiment does not provide an unequivocal demonstration of vasculogenesis because the Tie2 gene appears to be expressed in cell types other than endothelia, including pericytes and macrophages (Kim et al., 2000; Uchida et al., 2000; Shahrara et al., 2002). The results of the present study do not support the occurrence of vasculogenesis in the adult brain. Even in the subgranular zone of the dentate gyrus, where up to $37 \%$ of proliferating cells are represented by endothelia (Palmer et al., 2000), we did not observe a single GFP-labeled cell that exhibited endothelial characteristics. Although donor-derived 

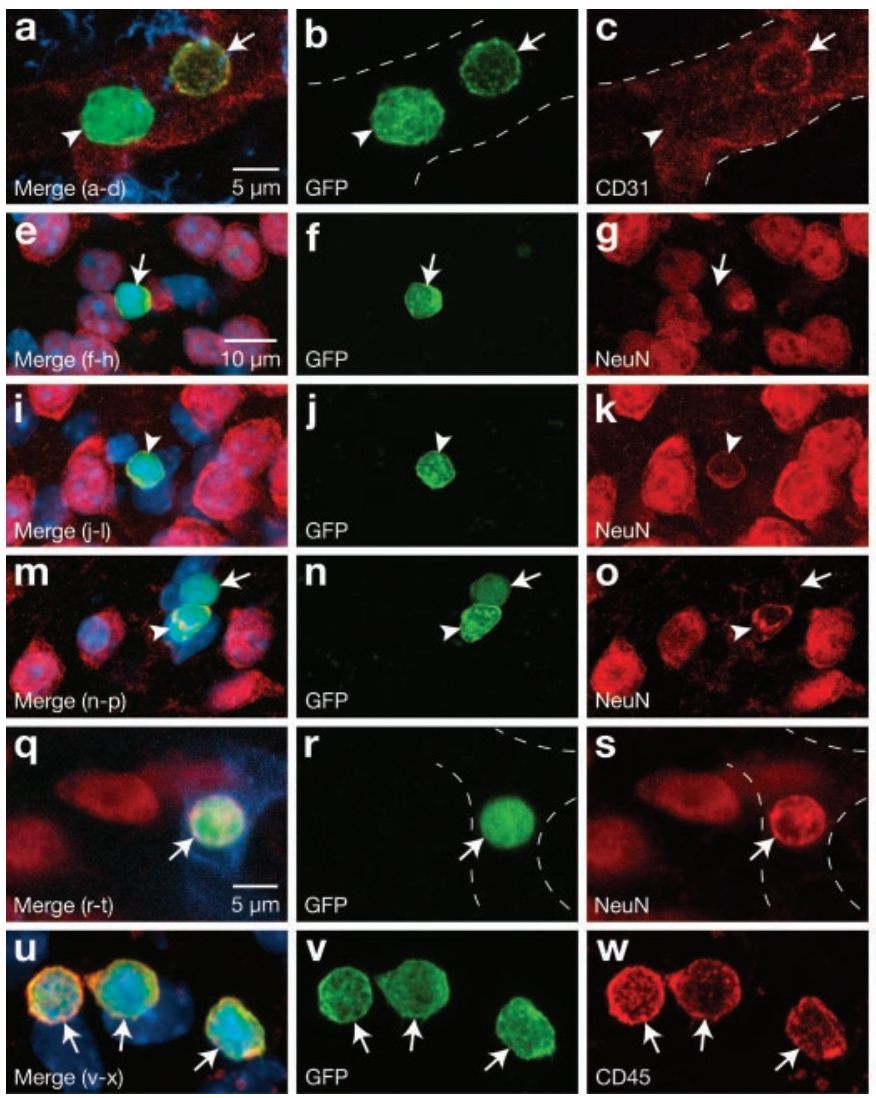

Figure 7. Phenotype of donor-derived cells with a round morphology. $a-d$, Confocal images showing round GFP-positive cells (green) located within a blood vessel (red) that were either CD31-Iba1-positive (arrow) or CD31-positive-Iba1-negative (arrowhead). $e-p$, GFP-positive cells (green) counterstained with DAPI (blue) that labeled negatively (arrows) or positively (arrowheads) for NeuN (red). $q-t$, Example of a donor-derived cell (green, arrows) that was positive for NeuN (red) and located within a blood vessel (blue). Note that NeuN-positive donor-derived cells are smaller than surrounding neurons. $u-x$, GFP-labeled cells (green, arrows) counterstained with DAPI (blue) that expressed CD45 (red). Scale bars: (in $a, q$ ) $a-d, q-x, 5 \mu \mathrm{m}$; (in $e$ ) $e-p, 10 \mu \mathrm{m}$.
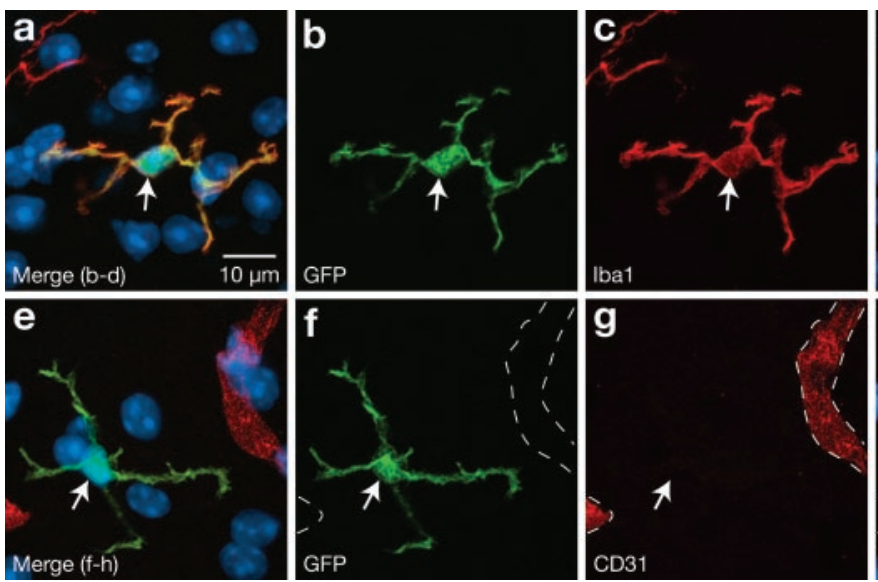

Figure 8. Phenotype of donor-derived cells with a stellate morphology. $a-h$, Confocal images showing GFP-positive stellate cells (arrows) in the cerebellum that were positive for lba1 $(a-d)$ and not associated with CD31-positive endothelium (e-h). Scale bar, $10 \mu \mathrm{m}$.

cells were unable to restore the population of proliferating endothelial cells depleted by irradiation and did not contribute to blood vessel rearrangement after an aspiration lesion of the cerebral cortex, we cannot definitively exclude the possibility that certain pathological conditions may trigger vasculogenesis in the mature brain.

The cerebral vasculature is believed to be surrounded by two
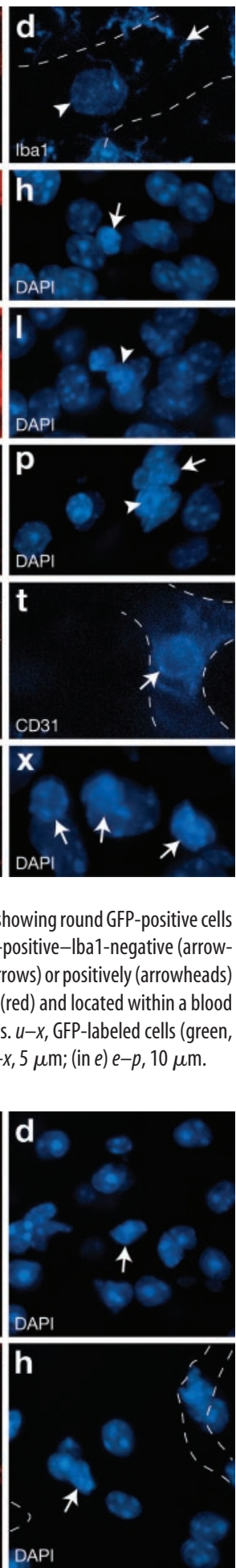

subsets of macrophages, namely pericytes and perivascular cells (Thomas, 1999). The main feature usually used to define them is their position relative to the extracellular vascular membranes; pericytes are contained within the endothelial basal lamina, whereas perivascular cells are located between this basement membrane and the glia limitans. Our results do not support the existence of two distinct populations of vessel-associated macrophages because every cell visualized by electron microscopy occupied a position ascribed to perivascular cells. Macrophages found by other investigators to be embedded in the vascular basal lamina may constitute intermediate forms between monocytes and perivascular cells. As elongated and amoeboid cells exhibit similar morphological characteristics as peripheral pericytes (Morikawa et al., 2002), they are likely to be equivalent in term of function, although some phenotypic differences may exist. Note that distinguishing markers for mouse perivascular cells have not yet been identified and, hence, it is not possible to selectively identify these cells with immunohistochemical techniques. Interestingly, perivascular cells express lower levels of Ibal than microglia, providing a useful mean to stain and distinguish both cell types, and underscoring the fact that these cells are functionally and phenotypically distinct (Streit et al., 1999). In addition to their classical roles in innate immunity as phagocytic and antigenpresenting cells, perivascular cells are believed to contribute to the structural stability of blood vessels, regulate endothelial cell proliferation, modulate blood-brain barrier properties, and initiate central acute phase responses by producing prostaglandins (Stoll and Jander, 1999; Thomas, 1999; Rucker et al., 2000; Schiltz and Sawchenko, 2002). Consistent with these functions, these cells appear to be involved in neural repair and many pathological processes such as entry of the AIDS virus into the brain, microaneurysm formation, stroke, multiple sclerosis, amyotrophic lateral sclerosis, Alzheimer's disease, and tumor growth (Stoll and Jander, 1999; Thomas, 1999; Rucker et al., 2000).

Our findings indicate a continuous traffic of immune cells in cerebral tissue, which is accelerated after injury. Leptomeningeal macrophages and perivascular cells appear to be replenished primarily from the recruitment of circulating precursors and, to a lesser extent, from the proliferation of preexisting macrophages at an overall rate that is likely to lead to complete turnover of the population within a year. Furthermore, whereas our observations in most brain regions are consistent with the view that microglia comprise a stable population that exhibits 
little or no turnover from circulating precursors, the cerebellum was identified as a notable exception. The mechanisms underlying the ability of donor-derived cells to give rise to microglia, preferentially in the molecular layer of the cerebellum, and the functional significance of this process remain to be determined.

In summary, this study provides a comprehensive phenotypic profile of the cells that access the adult brain under normal (i.e., nonpathological) conditions and after insult. Their predominant identification as macrophages suggests several ways in which their properties might be exploited for therapeutic purposes. For example, it may be advantageous to stimulate or supplement the formation of phagocytic cells after injury to accelerate recovery and repair. Because ablation of perivascular and meningeal macrophages has been found to alter the progression of animal models of multiple sclerosis and meningitis (Polfliet et al., 2001, 2002), it may be beneficial to manipulate the complement of such macrophages to mitigate these and other pathologies. Another attractive idea would be to exploit bone marrow cells as vehicles to introduce therapeutic genes into the nervous system to intervene in a range of pathological conditions. Although the feasibility of such approaches has been established (Hahn et al., 1998; Priller et al., 2001b), their translation to a clinical setting will require a better understanding of the regulatory mechanisms that govern the postnatal formation of microglia and perivascular cells, as well as the functions of these newly formed cells and their response to injury and involvement in pathogenic processes. It also remains to be determined whether, and under what conditions, subpopulations of cerebral macrophages can be distinguished, which might provide a basis for regionally targeted delivery and expression of therapeutic genes.

\section{References}

Abercrombie M (1946) Estimation of nuclear population from microtome sections. Anat Rec 94:239-247.

Akiyama Y, Radtke C, Kocsis JD (2002) Remyelination of the rat spinal cord by transplantation of identified bone marrow stromal cells. J Neurosci 22:6623-6630.

Anderson DJ, Gage FH, Weissman IL (2001) Can stem cells cross lineage boundaries? Nat Med 7:393-395.

Asahara T, Isner JM (2002) Endothelial progenitor cells for vascular regeneration. J Hematother Stem Cell Res 11:171-178.

Bjorklund A, Svendsen CN (2001) Chimeric stem cells. Trends Mol Med 7:144-146.

Blau HM, Brazelton TR, Weimann JM (2001) The evolving concept of a stem cell: entity or function? Cell 105:829-841.

Bonilla S, Alarcon P, Villaverde R, Aparicio P, Silva A, Martinez S (2002) Haematopoietic progenitor cells from adult bone marrow differentiate into cells that express oligodendroglial antigens in the neonatal mouse brain. Eur J Neurosci 15:575-582.

Brazelton TR, Rossi FM, Keshet GI, Blau HM (2000) From marrow to brain: expression of neuronal phenotypes in adult mice. Science 290:1775-1779.

Cameron HA, McKay RD (2001) Adult neurogenesis produces a large pool of new granule cells in the dentate gyrus. J Comp Neurol 435:406-417.
Castro RF, Jackson KA, Goodell MA, Robertson CS, Liu H, Shine HD (2002) Failure of bone marrow cells to transdifferentiate into neural cells in vivo. Science 297:1299.

Corti S, Locatelli F, Strazzer S, Salani S, Del Bo R, Soligo D, Bossolasco P, Bresolin N, Scarlato G, Comi GP (2002) Modulated generation of neuronal cells from bone marrow by expansion and mobilization of circulating stem cells with in vivo cytokine treatment. Exp Neurol 177:443-452.

Davis EJ, Foster TD, Thomas WE (1994) Cellular forms and functions of brain microglia. Brain Res Bull 34:73-78.

Eglitis MA, Mezey E (1997) Hematopoietic cells differentiate into both microglia and macroglia in the brains of adult mice. Proc Natl Acad Sci USA 94:4080-4085.

Fuchs E, Segre JA (2000) Stem cells: a new lease on life. Cell 100:143-155. Gage FH (2000) Mammalian neural stem cells. Science 287:1433-1438.

Hahn CN, del Pilar Martin M, Zhou XY, Mann LW, d'Azzo A (1998) Correction of murine galactosialidosis by bone marrow-derived macrophages overexpressing human protective protein/cathepsin A under control of the colony-stimulating factor-1 receptor promoter. Proc Natl Acad Sci USA 95:14880-14885.

Ito D, Imai Y, Ohsawa K, Nakajima K, Fukuuchi Y, Kohsaka S (1998) Microglia-specific localization of a novel calcium binding protein, Ibal. Brain Res Mol Brain Res 57:1-9.

Kalka C, Masuda H, Takahashi T, Kalka-Moll WM, Silver M, Kearney M, Li T, Isner JM, Asahara T (2000) Transplantation of ex vivo expanded endothelial progenitor cells for therapeutic neovascularization. Proc Natl Acad Sci USA 97:3422-3427.

Kanazawa H, Ohsawa K, Sasaki Y, Kohsaka S, Imai Y (2002) Macrophage/ microglia-specific protein Ibal enhances membrane ruffling and Rac activation via phospholipase C-gamma-dependent pathway. J Biol Chem 277:20026-20032.

Kim I, Kim JH, Ryu YS, Jung SH, Nah JJ, Koh GY (2000) Characterization 
and expression of a novel alternatively spliced human angiopoietin-2. J Biol Chem 275:18550-18556.

Kocher AA, Schuster MD, Szabolcs MJ, Takuma S, Burkhoff D, Wang J, Homma S, Edwards NM, Itescu S (2001) Neovascularization of ischemic myocardium by human bone-marrow-derived angioblasts prevents cardiomyocyte apoptosis, reduces remodeling and improves cardiac function. Nat Med 7:430-436.

Kohyama J, Abe H, Shimazaki T, Koizumi A, Nakashima K, Gojo S, Taga T, Okano H, Hata J, Umezawa A (2001) Brain from bone: efficient "metadifferentiation" of marrow stroma-derived mature osteoblasts to neurons with Noggin or a demethylating agent. Differentiation 68:235-244.

Kopen GC, Prockop DJ, Phinney DG (1999) Marrow stromal cells migrate throughout forebrain and cerebellum, and they differentiate into astrocytes after injection into neonatal mouse brains. Proc Natl Acad Sci USA 96:10711-10716.

Kruger GM, Mosher JT, Bixby S, Joseph N, Iwashita T, Morrison SJ (2002) Neural crest stem cells persist in the adult gut but undergo changes in self-renewal, neuronal subtype potential, and factor responsiveness. Neuron 35:657-669.

Lawson LJ, Perry VH, Gordon S (1992) Turnover of resident microglia in the normal adult mouse brain. Neuroscience 48:405-415.

Li Y, Chen J, Chopp M (2001) Adult bone marrow transplantation after stroke in adult rats. Cell Transplant 10:31-40.

Ling ZD, Potter ED, Lipton JW, Carvey PM (1998) Differentiation of mesencephalic progenitor cells into dopaminergic neurons by cytokines. Exp Neurol 149:411-423.

Lu D, Li Y, Wang L, Chen J, Mahmood A, Chopp M (2001) Intraarterial administration of marrow stromal cells in a rat model of traumatic brain injury. J Neurotrauma 18:813-819.

Mezey E, Chandross KJ, Harta G, Maki RA, McKercher SR (2000) Turning blood into brain: cells bearing neuronal antigens generated in vivo from bone marrow. Science 290:1779-1782.

Mezey E, Key S, Vogelsang G, Szalayova I, Lange GD, Crain B (2003) Transplanted bone marrow generates new neurons in human brains. Proc Natl Acad Sci USA 100:1364-1369.

Morikawa S, Baluk P, Kaidoh T, Haskell A, Jain RK, McDonald DM (2002) Abnormalities in pericytes on blood vessels and endothelial sprouts in tumors. Am J Pathol 160:985-1000.

Nakano K, Migita M, Mochizuki H, Shimada T (2001) Differentiation of transplanted bone marrow cells in the adult mouse brain. Transplantation 71:1735-1740.

Palmer TD, Willhoite AR, Gage FH (2000) Vascular niche for adult hippocampal neurogenesis. J Comp Neurol 425:479-494.

Papadimitriou JM, Walters MN (1979) Macrophage polykarya. CRC Crit Rev Toxicol 6:211-255.

Polfliet MM, Zwijnenburg PJ, van Furth AM, van der Poll T, Dopp EA, Renardel de Lavalette C, van Kesteren-Hendrikx EM, van Rooijen N, Dijkstra CD, van den Berg TK (2001) Meningeal and perivascular macrophages of the central nervous system play a protective role during bacterial meningitis. J Immunol 167:4644-4650.

Polfliet MM, van de Veerdonk F, Dopp EA, van Kesteren-Hendrikx EM, van Rooijen N, Dijkstra CD, van den Berg TK (2002) The role of perivascular and meningeal macrophages in experimental allergic encephalomyelitis. J Neuroimmunol 122:1-8.

Priller J, Persons DA, Klett FF, Kempermann G, Kreutzberg GW, Dirnagl U (2001a) Neogenesis of cerebellar Purkinje neurons from gene-marked bone marrow cells in vivo. J Cell Biol 155:733-738.

Priller J, Flugel A, Wehner T, Boentert M, Haas CA, Prinz M, Fernandez-Klett F, Prass K, Bechmann I, de Boer BA, Frotscher M, Kreutzberg GW, Persons DA, Dirnagl U (2001b) Targeting gene-modified hematopoietic cells to the central nervous system: use of green fluorescent protein uncovers microglial engraftment. Nat Med 7:1356-1361.

Rucker HK, Wynder HJ, Thomas WE (2000) Cellular mechanisms of CNS pericytes. Brain Res Bull 51:363-369.
Sanchez-Ramos J, Song S, Cardozo-Pelaez F, Hazzi C, Stedeford T, Willing A, Freeman TB, Saporta S, Janssen W, Patel N, Cooper DR, Sanberg PR (2000) Adult bone marrow stromal cells differentiate into neural cells in vitro. Exp Neurol 164:247-256.

Schiltz JC, Sawchenko PE (2002) Distinct brain vascular cell types manifest inducible cyclooxygenase expression as a function of the strength and nature of immune insults. J Neurosci 22:5606-5618.

Schmued LC, Albertson C, Slikker Jr W (1997) Fluoro-Jade: a novel fluorochrome for the sensitive and reliable histochemical localization of neuronal degeneration. Brain Res 751:37-46.

Shahrara S, Volin MV, Connors MA, Haines GK, Koch AE (2002) Differential expression of the angiogenic Tie receptor family in arthritic and normal synovial tissue. Arthritis Res 4:201-208.

Shintani S, Murohara T, Ikeda H, Ueno T, Sasaki K, Duan J, Imaizumi T (2001) Augmentation of postnatal neovascularization with autologous bone marrow transplantation. Circulation 103:897-903.

Stoll G, Jander S (1999) The role of microglia and macrophages in the pathophysiology of the CNS. Prog Neurobiol 58:233-247.

Streit WJ, Walter SA, Pennell NA (1999) Reactive microgliosis. Prog Neurobiol 57:563-581.

Takahashi T, Kalka C, Masuda H, Chen D, Silver M, Kearney M, Magner M, Isner JM, Asahara T (1999) Ischemia- and cytokine-induced mobilization of bone marrow-derived endothelial progenitor cells for neovascularization. Nat Med 5:434-438.

Taylor MV (2002) Muscle differentiation: how two cells become one. Curr Biol 12:R224-R228.

Terada N, Hamazaki T, Oka M, Hoki M, Mastalerz DM, Nakano Y, Meyer EM, Morel L, Petersen BE, Scott EW (2002) Bone marrow cells adopt the phenotype of other cells by spontaneous cell fusion. Nature 416:542-545.

Thomas WE (1999) Brain macrophages: on the role of pericytes and perivascular cells. Brain Res Brain Res Rev 31:42-57.

Uchida N, He D, Friera AM, Reitsma M, Sasaki D, Chen B, Tsukamoto A (1997) The unexpected G0/G1 cell cycle status of mobilized hematopoietic stem cells from peripheral blood. Blood 89:465-472.

Uchida T, Nakashima M, Hirota Y, Miyazaki Y, Tsukazaki T, Shindo H (2000) Immunohistochemical localization of protein tyrosine kinase receptors Tie- 1 and Tie-2 in synovial tissue of rheumatoid arthritis: correlation with angiogenesis and synovial proliferation. Ann Rheum Dis 59:607-614.

Wagers AJ, Sherwood RI, Christensen JL, Weissman IL (2002) Little evidence for developmental plasticity of adult hematopoietic stem cells. Science 297:2256-2259.

Weimann JM, Charlton CA, Brazelton TR, Hackman RC, Blau HM (2003) Contribution of transplanted bone marrow cells to Purkinje neurons in human adult brains. Proc Natl Acad Sci USA 100:2088-2093.

Weissman IL (2000) Stem cells: units of development, units of regeneration, and units in evolution. Cell 100:157-168.

Wells WA (2002) Is transdifferentiation in trouble? J Cell Biol 157:15-18.

Woodbury D, Schwarz EJ, Prockop DJ, Black IB (2000) Adult rat and human bone marrow stromal cells differentiate into neurons. J Neurosci Res 61:364-370.

Wright DE, Wagers AJ, Gulati AP, Johnson FL, Weissman IL (2001) Physiological migration of hematopoietic stem and progenitor cells. Science 294:1933-1936.

Ying QL, Nichols J, Evans EP, Smith AG (2002) Changing potency by spontaneous fusion. Nature 416:545-548.

Zhang ZG, Zhang L, Jiang Q, Chopp M (2002) Bone marrow-derived endothelial progenitor cells participate in cerebral neovascularization after focal cerebral ischemia in the adult mouse. Circ Res 90:284-288.

Zhao LR, Duan WM, Reyes M, Keene CD, Verfaillie CM, Low WC (2002) Human bone marrow stem cells exhibit neural phenotypes and ameliorate neurological deficits after grafting into the ischemic brain of rats. Exp Neurol 174:11-20. 